\title{
EFFECT OF YOGIC PRACTICES AND WALKING EXERCISES ON HEALTH RELATED PHYSICAL FITNESS - A COMPARATIVE STUDY ON FEMALE STUDENTS
}

\author{
DR.UDAY MANJRE* \\ Assistant Professor, Shree H.V.P.Mandal's Degree College of Physical Education, Amravati-444 605, Maharashtra, India \\ *Corresponding Author Ph: (0721) 2573788; Email: udaymanjre@yahoo.com
}

\section{DOI: 10.26524/1234}

\begin{abstract}
The purpose of the study was to find the comparative effect of yogic practices and walking exercises on health related physical fitness among the students of D.C.P.E. Amravati, For this research purpose 75 subjects were taken as female students from B.P. E. age ranged 18 to 21 years. The hypothesis is that, there will be no significant difference in HRPF components of yogic practices and walking exercises among the subjects. Thus, the pre test was administered and HRPF components (12 min run/walk, sit \& reach, sit ups, body composition) were as criterion measures variables. This is to find out pre test performance of the subjects. The data measured was into three homogenous equal groups (A-yogic practices),(B-walking exercises),( $C$ - control group).
\end{abstract}

There was immediate implementation of six weeks training programme of the both experimental groups, after that post test was conducted. One way analysis of variance as well as on Scheffe"s post HOC test was employed assesses the significant differenc e. The significant difference was found among yogic practices group in terms of flexibility and abdominal strength. Walking exercises group was more significant difference in cardiovascular endurance, and no change was found in body composition among all subjects.

Abbreviation: BPE- Bachelor of Physical Education, HRPF: Health related physical fitness.

Introduction

As per new research in health related physical fitness is very essential or basic need. It is also related to ability to meet the demands of the environment specifically to preserve, to withstand stress, to resist fatigue and to possess the energy for a $p$ lentiful life [124]. During studies, researcher have found that health related physical fitness may enhance in yogic practices and walking exercis es program done by improving and develop their daily routine activities [25-36]. Additionally previous investigations done related to this study investigated the effects of yogic practices and walking exercises on health related physical fitness improves [37-42].

The purpose of the current study was compare the pre and post exercises standard of health related physical fitness of yogic practices and walking exercises of students in D.C.P.E. Amravati.

\section{Methodology}

The present investigation was conducted on 75 female subjects, of BPE part II class of D.C.P.E. Amravati. They were divided into three equal groups of 25 subjects of each. The students were between 18 to 21 years of age group. Cardiovascular efficiency, Muscular Strength \& endurance, Flexibility and Body composition were delimited variables of the study. Independent variables in training programmer indicate that the yogic practices and walking exercises training was accepted in the training schedule.

\section{Criterion measures and tools used}

Cardiovascular endurance was assessed with the help of field event i.e, 12 min run-walk test and the scores were recorded in nearest 0.5 meter. Flexibility was measured by Cureton ${ }^{\text {ee }}$ s sit and reach box method the score was recorded nearest to 0.5 inch. Strength 
and endurance of abdominal muscles efficiency was measured by using sit ups test and score was recorded in number of sit up performed in one minute. Body fat was measured by skin fold caliper, body fat weight measured by four different sites of body of subject (Biceps, Triceps, Sub scapular, Suprailliac) and score was recorded in skin fold thickness $0.05 \mathrm{~mm}$.

\section{Administered of the pre test}

The researcher first administered the pre test. Pre test performances of the subjects was converted into composites scores an d divided into three different and equal homogenous groups. Experimental groups were trained for yogic practices and walking exercises. Further control group was not included for the training. The duration of the training programmer was six weeks. After completion of the training programmer the post test was administrated.

\section{Statistical procedure}

The data obtained was analyzed with the help of statistical software (SPSS 11.5). The researcher compared the performances on post test of three groups with the help of one way analysis primarily with descriptive statistics. Further 3 x 4 Factorial ANOVA followed by Schieffe

\section{Training programmed of Yoga Practice Schedule in First and Second Weeks}

\begin{tabular}{ccccc}
\hline Sr.No. & Asana & Time & Relaxation Duration & Repetition \\
\hline 1 & Padmasana & $1 \mathrm{~min}$ & $20 \mathrm{sec}$ & 3 \\
2 & Vakrasana & $1 \mathrm{~min} 30 \mathrm{sec}$ & $30 \mathrm{sec}$ & 3 \\
3 & Supt Vajrasana & $30 \mathrm{sec}$ & $15 \mathrm{sec}$ & 3 \\
4 & Uttanpadasan & $20 \mathrm{sec}$ & $30 \mathrm{sec}$ & 3 \\
5 & Vipritkarni & $30 \mathrm{sec}$ & $30 \mathrm{sec}$ & 3 \\
6 & Dhanurasana & $20 \mathrm{sec}$ & $30 \mathrm{sec}$ & 3 \\
7 & Bhujangasana & $30 \mathrm{sec}$ & $20 \mathrm{sec}$ & 3 \\
8 & Tadasana & $30 \mathrm{sec}$ & $30 \mathrm{sec}$ & 3 \\
9 & Padahastasana & $30 \mathrm{sec}$ & $30 \mathrm{sec}$ & 3
\end{tabular}

Prayer - 5 min, Kapalbhati - 5 min, Pranayama (Anuloma-Viloma) with Omkar Japa - 10 min Total exercise and relaxation time per day $-35 \mathrm{~min}$

\section{Training programmed of Yoga Practice Schedule in Third and Fourth Week}

\begin{tabular}{clccc}
\hline Sr.No. & Asana & Time & Relaxation Duration & Repetition \\
\hline 1 & Vajrasana & $30 \mathrm{sec}$ & $20 \mathrm{sec}$ & 3 \\
2 & Ardha Mahchidrasana & $1 \mathrm{~min}$ & $30 \mathrm{sec}$ & 3 \\
3 & Gomukhasana & $1 \mathrm{~min}$ & $30 \mathrm{sec}$ & 3 \\
\hline
\end{tabular}




\begin{tabular}{llccc}
\hline 4 & Pachimottasana & $30 \mathrm{sec}$ & $20 \mathrm{sec}$ & 3 \\
5 & Sarvangasana & $1 \mathrm{~min}$ & $30 \mathrm{sec}$ & 3 \\
6 & Halasana & $1 \mathrm{~min}$ & $30 \mathrm{sec}$ & 3 \\
7 & Chakrasana & $30 \mathrm{sec}$ & $30 \mathrm{sec}$ & 3 \\
8 & Shalbhasana & $30 \mathrm{sec}$ & $30 \mathrm{sec}$ & 3 \\
9 & Bhujagasana & $30 \mathrm{sec}$ & $20 \mathrm{sec}$ & $2 \mathrm{~min}$
\end{tabular}

Prayer - 5 min, Kapalbhati - 5 min, Pranayama (Anuloma-Viloma) with Omkar Japa - 10 min, Total exercise and relaxation time per day $-35 \mathrm{~min}$

Training programmed of Yoga Practice Schedule in Fifth and Sixth Week

\begin{tabular}{|c|c|c|c|c|}
\hline Sr.No. & Asana & Time & Relaxation Duration & Repetition \\
\hline 1 & Padmasana & $30 \mathrm{sec}$ & & \\
\hline 2 & Ardha Machindrasana & $1 \mathrm{~min}$ & $30 \mathrm{sec}$ & 3 \\
\hline 3 & Pachimottasana & $1 \mathrm{~min}$ & $20 \mathrm{sec}$ & 4 \\
\hline 4 & Matyasana & $1 \mathrm{~min}$ & $20 \mathrm{sec}$ & 3 \\
\hline 5 & Sarvagasana & $1 \mathrm{~min}$ & $30 \mathrm{sec}$ & 4 \\
\hline 6 & Halasana & $1 \mathrm{~min}$ & $1 \mathrm{~min}$ & 4 \\
\hline 7 & Chakrasana & $30 \mathrm{sec}$ & $20 \mathrm{sec}$ & 3 \\
\hline 8 & Uttanpadasana & $30 \mathrm{sec}$ & $20 \mathrm{sec}$ & 3 \\
\hline 9 & Dhanurasana & $30 \mathrm{sec}$ & $20 \mathrm{sec}$ & 3 \\
\hline 10 & Shalbhasana & $20 \mathrm{sec}$ & $30 \mathrm{sec}$ & 2 \\
\hline 11 & Padasthasana & $30 \mathrm{sec}$ & $30 \mathrm{sec}$ & 3 \\
\hline 12 & Trikonasana & $1 \mathrm{~min}$ & $30 \mathrm{sec}$ & 2 \\
\hline 13 & Shavasana & & $3 \mathrm{~min}$ & \\
\hline
\end{tabular}

Prayer - 5 min, Kapalbhati - 3 min, Total exercise and relaxation time per day - 52 min.

Training program of walking exercises Schedule

\begin{tabular}{lllllll}
\hline Week & Specific & $\begin{array}{l}\text { Duration } \\
\text { (Min) }\end{array}$ & $\begin{array}{l}\text { Distance } \\
\text { (Meters) }\end{array}$ & $\begin{array}{l}\text { Relaxation } \\
\text { (Min) }\end{array}$ & $\begin{array}{l}\text { Stretching } \\
\text { Exercise }\end{array}$ & Duration \\
\hline First & Walking & 25 & 2000 & 10 & $-{ }^{\prime \prime}$ & 25 \\
Second & Walking & 30 & 2500 & 10 & $-{ }^{-}$ & 20 \\
\hline
\end{tabular}




\begin{tabular}{lllcccc}
\hline Third/Fourth & Walking & 35 & 3000 & 5 & $-’-$ & 20 \\
Fifth/Sixth & Walking & 40 & 3500 & 5 & $-”$ & 20 \\
\hline
\end{tabular}

TABLE NO. 1

ANOVA of 12 min Run \& Walk performance of yogic practices group, walking exercises group and control group.

\begin{tabular}{clllll}
\hline Source of Variation & S.S. & D.F. & M.S. & Obtained 'F' & Tabulated 'F' \\
\hline Between Group & 875203.3 & 2 & 18710.5 & & \\
\hline Within Group & 2026146.24 & 72 & 28140.92 & $6.774^{*}$ & 3.168 \\
\hline
\end{tabular}

*Significant at 0.05 level of confidence, Tabulated value $\mathrm{F}(0.05)(2,72)=3.168$

The below mentioned table shows that there was a significant difference between yogic practices group, walking exercises grou $\mathrm{p}$ and control group with the performance of $12 \mathrm{~min}$ run and walk test. As the obtained value „, $\mathrm{F}^{\mathrm{ec}} 6.774$ was greater than the tabulated „, $\mathrm{F}^{\mathrm{ec}}$ 3.168. The level of significance was set at 0.05 level of confidence.

TABLE NO. 2

Paired Mean difference at 12 min Run \& Walk Performance of yogic practices group, walking experience group and control group.

\begin{tabular}{lllll}
\hline Yoga & Walking & Control & & Critical \\
Group & Group & Group & M. D & Difference \\
\hline 1860 & 1920 & & 60 & \\
1860 & & 1715.5 & $144.5^{*}$ & 107.19 \\
& 1920 & 1715.5 & $205.5^{*}$ & \\
\hline
\end{tabular}

Difference between yoga group and Walking Group $=75$

Observed difference between yoga group and control group $=144.5$

Observed difference between walking group and control group $=205.5$

Table no. 2 shows that significant differences between the means of 12 min run and walk performance, yoga practice group and control group, which is 144.5 and walking exercises, and control group, which is more significant as compared to yoga group and control group. The level of significance was set at 0.05 level of confidence 
TABLE NO. 3

ANOVA of Sit and reach performance of yogic practices group, walking exercises group and control group.

\begin{tabular}{|c|c|c|c|c|c|}
\hline Source of Variation & S.S. & D.F. & M.S. & Obtained ' $F$ ' & Tabulated ' $F$ ' \\
\hline Between Group & 78.84 & 2 & 39.42 & \multirow[b]{2}{*}{$6.86^{*}$} & \multirow[b]{2}{*}{3.168} \\
\hline Within Group & 41328 & 72 & 574 & & \\
\hline
\end{tabular}

*Significant at 0.05 level of confidence, Tabulated value $\mathrm{F}(0.05)(2,72)=3.168$

It has been observed from the above mentioned table no. 2 that there was a significant difference between yoga practices grou p, walking exercises group and control group with the performance sit and reach test was significant, because the obtai ned „, $\mathrm{F}^{\mathrm{ee}} 6.86$ was greater that the tabulated „, $\mathrm{F}^{\mathrm{ec}} 3.168$ for which the level of significance was set at 0.05 level of confidence.

TABLE NO. 4

Paired Mean difference of Sit and Rich test Performance of yoga practices group, walking experience group and control group.

\begin{tabular}{llllc}
\hline Yoga Group & Walking Group & $\begin{array}{l}\text { Control } \\
\text { Group }\end{array}$ & M.D. & Critical Difference \\
\hline 9.88 & 8.42 & & 1.48 & 1.46 \\
9.88 & & 7.13 & $2.75^{*}$ & \\
& 8.42 & 7.13 & $1.29 *$ & \\
\hline
\end{tabular}

The „Fee at 0.05 level of significance for d.f. $=2,72$ is 3.168

Observed difference between yoga practice group and walking exercise group $=1.48$

Observed difference between yoga practice group and control group $=2.75$

Observed difference between walking exercises group and control group $=1.29$

Table no. 4 shows that significant difference between the means of sit \& reach test performance at yoga practices group and control group which is 2.75 and walking exercises and control group which is significant at 1.32 and no significant difference was in yoga practices group and walking exercises group, which is 1.48 . The level of significance was set at 0.05 level of confidence 
TABLE NO. 5

ANOVA of Sit ups performance of yoga practices group, walking exercises group and control group.

\begin{tabular}{llllll}
\hline \multicolumn{1}{c}{ Source of Variation } & S.S. & D.F. & M.S. & Obtained 'F' & Tabulated 'F' \\
\hline Between Group & 109.2 & 2 & 54.6 & & \\
\cline { 1 - 4 } & & & & & \\
\hline Within Group & 435.6 & 72 & 6.05 & & 3.168 \\
\hline
\end{tabular}

* Significant at 0.05 level of confidence, Tabulated value , $F^{e e}(0.05)(2,72)=3.168$

It has been observed from the above mentioned table no. 5 that there was a significant difference between yoga practices grou p, walking exercises group and control group with the performance of sit ups test which was significant, because the obtained „, $\mathrm{F}^{\mathrm{ee}} 9.82 \mathrm{was}$ greater than the tabulated , $F^{e e} 3.168$ for which the level of significance was set at 0.05 level of confidence.

TABLE NO. 6

Paired Mean difference of Sit Ups Performance of yoga practices group, walking experience group and control group.

\begin{tabular}{lllll}
\hline Walking Group & Yoga Group & Control Group & M.D. & $\begin{array}{l}\text { Critical } \\
\text { Difference }\end{array}$ \\
\hline 21.10 & 18.20 & & $2.90^{*}$ & \\
& 18.20 & 16.95 & 1.25 & \\
21.10 & & 16.95 & $4.15^{*}$ & \\
\hline
\end{tabular}

The „, $\mathrm{F}^{\mathrm{ee}}$ at 0.05 level of significance for d.f. $=2,72$ is 3.168

Observed difference between yoga practice group and walking exercise group $=2.90$

Observed difference between yoga practice group and control group $=1.25$

Observed difference between walking exercises group and control group $\quad=4.15$

Table no. 6 shows that significant difference between the means of sit ups performance of yoga practices group and walking exercises group which is 2.90 and walking exercises and control group which significant difference also 4.15 and no significant differe nce in yoga practices group and control group, which is 1.25 . The level of significance was set at 0.05 level of confidence.

TABLE NO. 7

ANOVA of Fat weight performance of yoga practices group, walking exercises group and control group.

\begin{tabular}{llllcc}
\hline \multicolumn{1}{c}{ Source of Variation } & S.S. & D.F. & M.S. & Obtained 'F' & Tabulated 'F' \\
\cline { 1 - 4 } Between Group & 19.27 & 2 & 9.63 & & \\
\cline { 1 - 4 } Within Group & 298.64 & 72 & 4.14 & 2.20 & 3.168 \\
\hline
\end{tabular}


* Significant at 0.05 level „, $\mathrm{F}^{\mathrm{ee}}$ confidence, Tabulated value „, $\mathrm{F}^{\mathrm{ee}}(0.05)(2,72)=3.168$

It had observed from the above mentioned table no. 7 that there was no significant difference between yoga practices group, a nd control group, walking exercises group and control group with the variables and fat weight because the obtained „F $\mathrm{F}^{\mathrm{ee}} 2.20$ was less than the tabulated , $\mathrm{F}^{\mathrm{ee}} 3.168$ for which the level of significance was set at 0.05 level of confidence.

TABLE NO. 8

Paired Mean difference of Fat Weight Performance of yoga practices group, walking experience group and control group.

\begin{tabular}{ccccc}
\hline Yoga Group & Walking Group & Control Group & M.D. & Critical Difference \\
\hline 249.80 & 237.62 & & 1.17 & \\
249.80 & & 213.45 & $36.35^{*}$ & 1.208 \\
& 236.70 & 213.45 & $24.17^{*}$ & \\
\hline
\end{tabular}

The „Fee at 0.05 level of significance for d.f. $=2,72$ is 3.168

Observed difference between yoga practice group and walking exercise group $=1.21$

Observed difference between yoga group and control group $=36.35$

Observed difference between walking exercises group and control group $=24.17$

Table no. 8 shows that significant difference between the means of fat weight performance, yoga practices group and control group which is 36.35 and walking exercise and control group which is significant difference also 24.17 and no significant difference in yoga practices group and walking exercises group which is 1.21 . The level of significance was set at 0.05 level of confidence.

\section{Discussion of Finding}

The study of comparative effect of selected yogic practices and walking exercises on health related physical fitness among th e students of Degree College of Physical Education, Amravati. Finding of the study indicated that, the significance between 12 min run /walk, sit and reach and sit-ups are significantly at 0.05 level of confidence with 72 degree of freedom. There was no significant difference in the fat weight of yogic practices, walking exercise and control groups.

\section{Conclusion}

Body composition shows no significant improvement of both experimental groups. Yogic practices fast improved the Health Relat ed Physical Fitness Components. Walking exercises did not show significant improvement in Health Related Physical Fitness Components, but walking exercises shows fast and (significant) improvement in cardiovascular endurance. Yogic practice shows significant improvement in flexibility.

\section{References}

[1]. J.W. Best \& V.J. Kahn, (2008) Research in Education, Edition tenth Pub. Dorling Kindersley, (I) Pvt. Ltd.

[2]. Clarke H Harrison (1976) Application of Movement in Physical Education, P.173.

[3]. Franks B. Don (2003). Health Fitness Instructors Handbook, Pub. Hong Kong. P. 23.

[4]. B. Getchell, (1979) Physical Fitness a way of life, New York, John Willey Cheonester Torouto, P.8. 
[5]. M. Gore (2005), Anatomy and physiology of Yogic practices, Pub, New age book, New Delhi, P.P. 99-100.

[6]. M.L.Gharote, (1982) Guideline for yogic practices, Pub. Medha, Lonawala, P. 10.

[7]. M.L. Gharote, and S. Digambarji (1984) Hathapradika India (Lonavala) Kdham SMYM Samiti. P.106.

[8]. Z.F. Gearle (1982) Physical Education \& Sports - An Introducation, Philadelphia: Leu \& Fobiger P.19.

[9]. V. Laskmi (2004) Physical Fitness, Pub Vivek Thani, P.248.

[10]. D. Larson (1966), A review of professional effort on the measurement of physical fitness, Pub. Tokyo. P 298.

[11]. National Sports Goods Association USA, (2004) FITNESS WALKING. Pub. Scotland. P.12.

[12]. President council on physical fitness and sports, (1997) Physical fitness. Research Digest I P.14.

[13]. H.M. Reet \& A.K. Uppal (1984) Foundation of physical education, Pub. Friend, Barada, P.287.

[14]. B.J.Sharkey, (2003) Fitness \& Health, Pub P.P. 142-143.

[15]. Snowdon Les. (2004) Fitness Walking, Pub. Scotland, P.34.

[16]. S. Sturrgress (2000), A Practical Guide to self Realization, Pub LONDON, P.XVI.

[17]. A. Singh. \& others (2006), Essential of Physical education, Pub. Kalyani P.319.

[18]. O.P. Tiwari (2000) Asana Why and How, Edition third, Pub Kaivalyadhama Samiti Lonavla.

[19]. A.K. Uppal, (2004) Physical Fitness and Wellness, Pub Friend, P.43.

[20]. J.C.P. Williams, (1965) A Medical aspect of sports and physical fitness, Oxford: pergamon P.23

[21]. Williams, (2000) Health Related Physical Fitness Assessment Manual. Pub. Lippincott. P.4.

[22]. Yankar Gary and Burton Kathy (1993) Walking Medicine, McGraw-Hill Inc P.25.

[23]. AAHPER Youth Fitness Test Manual, (1976 )Revised Ed., (Washington, D.C.,AAHPERD Publications,).

[24]. AAHPER (1984) Health related physical fitness Technical manual, Restone Va ; American Alliance For Health, Physical Education, Recreation And Dance.

[25]. T.A. Barton, (1963), A study to investigate the strength decrement of selected muscle group during treadmill walking at different grade levels while back-packing a prescribed load, M. S. in Phy. Edu. P.40

[26]. U. Bergh, Human power at subnormal body temperature, Acta Physiologica Scandinavica. Supplementum, 478 (1980) 1-39.

[27]. U. I. Berg, Physical performance and peak aerobic power at different body temperature, Journal of Applied Physiology, 46 (1986) 885-890

[28]. T.K. Bera, Physical Work Capacity and Oxygen Consumption in Exercise and Yoga, Yoga Mimamsa, 35 (2002) 183-192.

[29].K.A. Cameron, (1989), Effect of an aerobic movement programmer on CV fitness, body composition, and body esteem on overweight children. Health Physical Education Recreation and Dance,Vol-31, P.21-22

[30]. M.R. Davey, (1986), The effect of a structured walking/jogging program on the cardiovascular fitness, self-concept, and body image of mildly mentally retarded adults, University of Kansas, Dissertation Abstracts International., Vol.48 no.5, P.1145

[31]. H.A. De Vries, Physical Education Adult Fitness Programmer; Does Physical Activities Promote Relaxation?, Journal of Physical Education and Recreation, 46 (1975) 53 - 54.

[32]. S.K. Ganguly, Effect of yogic training on endurance and flexibility, Yoga Mimamsa, 27 (1989) 29-39.

[33]. C. Giri, Yoga and Physical Fitness in the special reference to athletics, AAHPER Quarterly Journal, 74 (1966) 26

[34]. M.L. Gharote, Effect of yogic exercise on the strength and endurance of the abdominal muscle of the female, Vyayam Vidnyan, 4 (1970) 11-13 
[35]. C. Giri, (1967), An evaluation and study of the effect of the short term yogic exercise on the general physical fitness of adolescent high school students as guessed on the basis of athletic pentathlon tests, AAHPER Quarterly Journal, P.12-16

[36]. G.W. Gleim, N.S. Stachenfeld. \& J.A Nicholas, (1990), The influence of flexibility on the economy of walking and jogging, Journal of Orthopedics Research. Vol.8, P. 814-823

[37]. R.D. Glenn, (1980), Effect of walking and jogging on the body composition and cardio respiratory system of adult, Dissertation Abstracts International, Vol.40, P.3874

[38]. S.K. Ghosh, (2003), Effect of Physical Exercise, Yoga practices and their Combined Training on Selected Physiological Variable among High School Boys, Yoga Mimamsa, Vol. 35, No.1-2, P.15-25

[39]. P.V. Karambelkar \& M.V. Bhole, Respiratory Studies During Kapalbhati For 1, 2, 3 and 5 Minutes, Yoga Mimamsa, 27 (1988) 69-74

[40]. V.K. Kanade \& M.L. Gharote, Effect of yogic training on physical fitness and selected Athletic Events, Yoga Mimamsa, 29 (1990) 56-66

[41]. A.M. Moorthy \& M.V. Bhole, Comparison of forward flexibility during doing oriented and feeling oriented asanas, Sports Medicine, 3 (1981) 1-3.

[42]. M.D. Polleck, Effect of walking on body composition and cardiovascular function of middle aged men, Journal of Applied Physiology, 30 (1971) 126-130. 